\title{
International law and transboundary aquifers
}

Gabriel Eckstein

Texas A\&M University School of Law, gabrieleckstein@law.tamu.edu

Follow this and additional works at: https://scholarship.law.tamu.edu/facscholar

Part of the International Law Commons, Law and Society Commons, and the Natural Resources Law Commons

\section{Recommended Citation}

Gabriel Eckstein, International law and transboundary aquifers, in Routledge Handbook of Water Law and Policy 217 (Alistair Rieu-Clark, Andrew Allan and Sarah Hendry eds., 2017).

Available at: https://scholarship.law.tamu.edu/facscholar/882

This Book Section is brought to you for free and open access by Texas A\&M Law Scholarship. It has been accepted for inclusion in Faculty Scholarship by an authorized administrator of Texas A\&M Law Scholarship. For more information, please contact aretteen@law.tamu.edu. 


\title{
17. International Law and Transboundary Aquifers
}

\author{
Gabriel E. Eckstein
}

\begin{abstract}
Although international law applicable to transboundary aquifers is still in an early stage of development, ground water resources on nation's frontiers are now garnering growing international attention. This article examines the chief formal and informal mechanisms that have been proposed or implemented for the assessment, use, allocation, and protection of transboundary aquifers and identifies the legal trends and priorities emerging from these instruments. It also considers gaps and shortcomings in the emerging administrative regime and offers recommendations for the further development of the law.
\end{abstract}

\section{Introduction}

Growing demands for fresh water resources coupled with declining supplies have exacerbated water scarcity around the world. As a result, many nations are focusing their attention on ground water supplies in order to meet their societal, economic, and environmental needs and objectives. Not surprising, they are finding that many of these subsurface water bodies are shared with their neighbors and pose unique transboundary political, social, and legal issues. This phenomenon is particularly evident in the Middle East where the use and allocation of aquifers traversing political boundaries, such as the Mountain Aquifer shared by Israelis and Palestinians and the Nubian Sandstone Aquifer shared by Chad, Egypt, Libya, and Sudan, continue to be a source of friction among overlying riparians.

At present, there are few concrete rules under international law that govern relations over cross-border ground water resources. The growing interest in transboundary aquifers, however, is spurring discussions and inquiry about the appropriate rules and mechanisms for exploiting and managing these buried treasures. Moreover, as nations around the world begin to extract (or intensify their withdrawals of) ground water from aquifers traversing national borders, they are beginning to explore and experiment with various approaches to address rights and obligations pertaining to these shared subsurface resources. As a result, while state practice in and scholarly analyses of the utilisation of transboundary aquifers are still relatively sparse, trends and priorities are beginning to emerge.

In an effort to identify and characterise these trends and priorities, this study reviews the chief formal and informal mechanisms that have been proposed or implemented for the assessment, use, allocation, and protection of transboundary ground water 
resources. The study begins by addressing the importance of transboundary aquifers as a source of fresh water for people and the environment. It then examines a number of formal and informal arrangements between nations for the assessment, use, allocation, and protection of transboundary ground water resources. By studying these regimes, this article attempts to identify trends and priorities that may implicate the emergence of generally accepted international legal norms applicable to transboundary aquifers. This study concludes that while the law of transboundary aquifers is in an early stage of development, there is, nonetheless, a growing body of experience and practice suggesting the emergence of legal standards. Lastly, the article considers the gaps and shortcomings in the emerging international regulatory system and offers recommendations for the further development of the law.

\section{Scope and significance of transboundary aquifers around the world}

Transboundary ground water resources play a critical role in providing fresh water for people, industries, nations, and the environment worldwide. This is especially true in the arid and semi-arid regions of the world where transboundary aquifers often serve as the primary or sole source of freshwater for human and environmental sustenance. Libya, for example, which has no meaningful surface water resources, obtains the majority of its fresh water - some 6.5 million cubic meters of water daily - from the Nubian Sandstone Aquifer, a vast underground reservoir that also underlies sections of Libya's neighbours: Chad, Egypt, and Sudan (Watkins, 2006). Similarly, Palestinians in the West Bank and Gaza obtain the great majority of their water from aquifers shared with Israel - the Mountain Aquifer underlying the West Bank and eastern Israel, and the Coastal Aquifer underlying Gaza's and Israel's Mediterranean coast (World Bank, 2009). In addition, transboundary aquifers serve as the sole source of fresh water for many of the communities along the Mexico-United States border, including the Mexican cities of Puerto Palomas, Naco, Nogales, Sonoyta, and Tecate, and their respective American sister cities of Columbus, Bisbee, Nogales, Lukeville, and Tecate (Eckstein, 2012).

Although the precise global significance and impact of these shared resources has escaped quantification, extrapolations from relevant studies and comparisons support the proposition that transboundary aquifers have become critical to human, economic, and environmental sustainability worldwide. For example, ground water today is the most extracted natural resource on the globe and provides water for twenty percent of irrigated agriculture, as well as more than half of humanity's freshwater for everyday uses such as drinking, cooking, and hygiene (Water for People 2003). Moreover, while 276 international watercourses traverse the world's international political boundaries (Wouters and Moynihan 2013), an ongoing study has identified more than 600 aquifers and aquifer bodies traversing the same frontiers (IGRAC 2015). Furthermore, while an estimated forty percent of the world's population reside in transboundary river basins around the world (UN Environmental Programme 2002), given that most domestic and internationally transboundary rivers have a hydraulically connected aquifer, and that 
there are scores of solitary fossil aquifers around the world that likewise traverse international political boundaries, it is logical to infer that a comparable if not larger number of people reside in the basins of transboundary aquifers globally.

Despite the relevance of transboundary aquifers to human existence, economic development, and environmental sustainability, policy and legal attention to these subsurface resources is a relatively recent phenomenon. While over 3,600 treaties relating to the use of transboundary surface waters have been catalogued since $805 \mathrm{CE}$, and over 400 since 1820 (Wolf 2002), the first agreement to focus exclusively on the management of a transboundary aquifer occurred in 1978 for the Genevese Aquifer along the French-Swiss border (Genevese Convention, 2008).

Since then, greater attention has been focused on ground water resources traversing international boundaries and the legal, policy, and political considerations that pertain to these international water bodies. In addition to the Genevese Convention, a small handful of formal and informal arrangements have been forged for a number of other transboundary aquifers, including: the Guarani Aquifer in South America, the Nubian Sandstone and North Western Sahara aquifer systems in Northern Africa, the Al-Sag/AlDisi Aquifer shared between Jordan and Saudi Arabia, the Iullemeden and Taoudeni/Tanezrouft aquifer systems in West Africa, the Hueco Bolson aquifer underlying the cities of Juárez and El Paso on the Mexico-US border, and the Abbotsford-Sumas Aquifer between the US state of Washington and the Canadian province of British Columbia. In addition, transboundary ground water resources have featured prominently in the 1992 United Nations Economic Commission for Europe (UNECE) Convention on the Protection and Use of Transboundary Watercourses and International Lakes (1992 UNECE Water Convention), and the 1997 UN Convention on the Non-navigational Uses of International Watercourses (1997 UN Watercourses Convention).

Especially prominent in this evolutionary process are two documents proffering possible norms for administering transboundary ground water resources. The first are the nineteen draft articles on the law of transboundary aquifers (Draft Articles) prepared by the UN International Law Commission (UNILC) and submitted to the UN General Assembly (UNGA) in 2008. The second are the nine Model Provisions on Transboundary Groundwaters (Model Provisions) that were prepared under the auspices of the UNECE (Model Provisions 2014). While the outcome of the Draft Articles before the UNGA is still unresolved and the Model Provisions were intentionally proposed as exemplars, the two efforts represent significant milestones in the growing importance of transboundary aquifers on the international agenda. Concerns over aquifers shared by multiple nations are no longer secondary to those of surface water resources. Transboundary aquifers have come into their own and are now legitimate topics of international law, policy, and relations. 


\section{Examples of cooperative mechanisms for transboundary aquifers}

References to transboundary ground water resources have appeared in international instruments for more than 150 years. For example, an 1864 agreement between Portugal and Spain afforded both parties the common rights to springs located on the border (Treaty of Limits between Portugal and Spain, 1864). Similarly, an 1888 agreement between the United Kingdom and France provided both parties the common rights to use the wells of Hadou, which lay on the newly created border of the Somali coast. All of these references, however, were secondary or even tertiary concerns under their respective agreement. It wasn't until the late twentieth century that transboundary aquifers began garnering an interest warranting individualized attention in both treaty-making and international law.

The following section summarizes the chief formal and informal mechanisms that have been proposed or implemented on a transboundary aquifer. All but three of these arrangements are exclusively focused on aquifers. While the other three arrangements address other water resources, they are included in this study because of their relevance and emphasis on a particular transboundary aquifer as a primary concern.

\section{Formal Agreements}

The best known, and still the only treaty crafted to manage and specifically allocate the waters of a transboundary aquifer, is the Convention on the Protection, Utilization, Recharge and Monitoring of the Franco-Swiss Genevese Aquifer (Genevese Convention, 2008). Originated in 1978 and revised in 2008, this singular arrangement addresses ground water quality, quantity, abstraction, and recharge largely through the creation of a joint Genevese Aquifer Management Commission. While the Commission only has consultative status, its recommendations and technical opinions carry considerable weight in the management of the aquifer. In addition, the updated regime reasserts the Swiss artificial recharge obligations created by the original 1978 agreement, allocates expenses between the countries for the Swiss recharge efforts, and places strict withdrawals limits on extraction in France (see Preamble, Articles 2.3, 8, 11-14, and Annex to the Convention on the Inventory of the recharge equipment and existing extraction works). The Genevese Convention is particularly significant because it strikes a balance between state sovereignty and state responsibility in its management scheme, which is based almost exclusively on principles of transparency, good faith dealings, and cooperation. Moreover, the agreement is unique in its structure as a treaty since it provides purely technical mechanisms for managing the shared aquifer and avoids any direct political, legal, or other reference to either country's sovereign rights to the aquifer or its waters (Genevese Convention, 2008).

The newest arrangement for a transboundary aquifer is the 2015 Agreement between the Government of the Hashemite Kingdom of Jordan and the Government of the Kingdom 
of Saudi Arabia for the Management and Utilization of the Ground Waters in the AlSag/Al-Disi Layer (Al-Sag/Al-Disi Agreement, 2015). In contrast to the Genevese Convention, the Al-Sag/Al-Disi Agreement was created for the limited purpose of restricting ground water extraction and protecting ground water quality. While it imposes no numerical limitations on abstraction, the agreement creates a "Protected Area" or buffer zone in both countries from which ground water extraction is absolutely prohibited, as well as a broader "Management Area" from which extractions are restricted exclusively for municipal purposes. In a similar restrictive vein, the agreement places a near absolute prohibition on ground water pollution within the Management Area. Also significant is the Al-Sag/Al-Disi Agreement's creation of a Joint Technical Committee (JTC), which like the Genevese Commission, does not have any decision-making authority (Al-Sag/Al-Disi Agreement, 2015). While the JTC is responsible for monitoring both the quantity and quality of extractions, collecting and exchanging information, analyzing collected data, and submitting their findings to the competent authorities in both nations, it is yet unclear whether it will enjoy a strong consultative role as does the Genevese Commission.

Similar in concept to the Al-Sag/Al-Disi Agreement, the 1973 amendment to the 1944 Mexico-US Treaty Relating to the Utilization of Waters of the Colorado and Tijuana Rivers and of the Rio Grande known as Minute 242 also focused on restrictions to ground water extractions on the border (Minute 242,1973). While the Minute was designed to address salinity levels in the Colorado River, paragraphs five and six deviated from that purpose and focused on ground water in the Arizona-Sonora border region near San Luis. Paragraph five limits ground water pumping in this region to specifically enumerated withdrawal targets, while paragraph six requires both countries to consult each other prior to pursuing new development of surface or ground water resources anywhere on the border that could have adverse transboundary impacts (Minute 242, 1973). While paragraph five also referenced the future development of a border-wide ground water agreement, that arrangement has yet to be realised.

Taking a more generalist approach, the 2009 Agreement on the Guarani Aquiferentered into by Argentina, Brazil, Paraguay, and Uruguay - provides a basic framework for cooperating over the Guarani Aquifer (Guarani Agreement 2009). While the agreement references a number of broadly accepted substantive principles of international water law, including those of reasonable and equitable use (Articles $3 \& 4$ ) and of no significant harm (Articles 3, 6, \& 7), it does not elaborate on their definition or implementation. For example, the agreement does not identify the factors relevant to assessing whether a particular use is reasonable and equitable. In the same vein, the Guarani Agreement references various procedural obligations using vague terminology and qualifications, including those for sharing information (Articles 8, 9 \& 12), providing notification of planned measures that may result in a transboundary impact (Articles 9, 10, \& 11), and the creation of a commission to oversee cooperation (Article 15). For example, in obligating the sharing of information, Article 8 qualifies the 
requirement by requiring the Parties to "proceed to adequately exchange technical information about studies, activities and works that contemplate the sustainable use of the Guarani Aquifer System water resources" (Guarani Agreement 2009). While these formulations might be regarded as creating ambiguous obligations, they may also be perceived as creating a necessarily flexible framework for cooperation (Sindico \& Hawkins, 2015).

The most provocative aspect of the Guarani Agreement is its endorsement of state sovereignty over portions of the aquifer that underlay each nation (Article 2). While some assert that this language harkens back to the long-discredited Harmon Doctrine and is scientifically and politically indefensible (McCaffrey, 2011), others contend that the approach follows on the international notion of state sovereignty over natural resources and was necessary to achieve dialogue over this nascent topic (Villar \& Ribeiro, 2013). Notwithstanding its implications for evolving international law for transboundary aquifers, the Guarani Agreement has still not entered into force. While Uruguay and Argentina have ratified the instrument, Paraguay and Brazil have yet to do so.

Two additional arrangements must be considered when discussing formal mechanisms developed for addressing shared ground water resources. The first is actually a series of agreements entered into for the management of the Nubian Sandstone Aquifer in Norther Africa. The series begins with the 1992 Constitution of the Joint Authority for the Study and Development of the Nubian Sandstone Aquifer Waters (NSA Constitution 1992), which created a cooperative mechanisms designed to collect and compile information on the aquifer, promote cooperation, and develop common water management policies. That instrument was followed in 2000 by two agreements under the framework of a Programme for the Development of a Regional Strategy for the Utilisation of the Nubian Sandstone Aquifer System (NSAS Agreements 2000). Under the first agreement - Agreement No. 1 - Terms of Reference for the Monitoring and Exchange of Groundwater Information of the Nubian Sandstone Aquifer System, done in Tripoli - the four Parties consent to share via an Internet portal data that had been previously compiled in the Nubian Aquifer Regional Information System, as well as information on developmental aspects related to the aquifer, such as socio-economic data, environmental issues, drilling experiences, meteorological data, and other data. Under the second agreement - Agreement No. 2 - Terms of Reference for Monitoring and Data Sharing, done in Tripoli - the Parties agree to continuously update this information by monitoring the aquifer through specified studies, measurements, and analyses (NSAS Agreements 2000).

The second noteworthy arrangement, which was implemented in 2002, is entitled Establishment of a Consultation Mechanism for the Northwestern Sahara Aquifer System (NWSAS Agreement 2002). This second North African arrangement creates a regime whose mandate is to "coordinate, promote and facilitate the rational management of the 
NWSAS water resources." As part of its duties, the Consultative Mechanism must: (a) manage a hydrogeologic database and simulation model; (b) develop and oversee a reference observation network; (c) process, analyse, and validate data relating to knowledge of the NWSAS; (d) develop databases on socio-economic activities in the region related to water uses; (e) develop and publish indicators on the NWSAS and its uses; (f) promote and facilitate joint or coordinated studies and research; (g) formulate and implement training programs; (h) regularly update the NWSAS model; and (i) develop proposals for the continued evolution of the consultation mechanism.

\section{Informal Arrangements}

Formal agreements are not the only evidence of trends and priorities in the

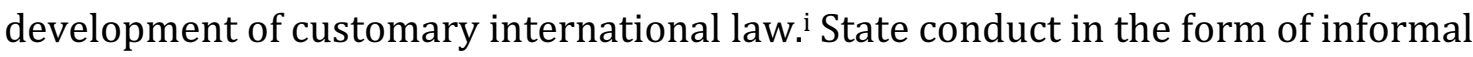
arrangements can also serve as indications of emerging State practice.

One of the more fascinating arrangements is the 2014 Memorandum of Understanding for the Establishment of a Consultation Mechanism for the Integrated Management of the Water Resources of the Iullemeden, Taoudeni/Tanezrouft Aquifer System (ITAS) entered into by Algeria, Benin, Burkina Faso, Mali, Mauritania, Niger, and Nigeria (ITAS MoU, 2014). ${ }^{\text {ii }}$ As noted by its title, the focus of this arrangement is on the creation of a Consultative Mechanism tasked with promoting cooperation over the management of both the Iullemeden Aquifer System and the Taoudeni/Tanezrouft Aquifer System. More specifically, the Mechanism is responsible inter alia for: conducting joint studies; formulating recommendations for harmonizing water-related legislative, institutional and management framework, as well as procedures and policies; and settling disputes between the Parties (Article 5). In contrast to the purely consultative status of the Genevese Aquifer Management Commission and the Joint Technical Committee under the Al-Sag/Al-Disi Agreement, or the unclear status of the commission under the Guarani Agreement, the Consultative Mechanism under the ITAS MoU has legal personality and authority to contract, acquire and dispose of property, seek and obtain loans, gifts, and technical assistance, and be a party in legal proceedings (Article 6). In addition, and in stark contrast to the Genevese Convention, the ITAS MoU explicitly relies on the well-known international water and environmental law principles of equitable and reasonable utilisation, no harm, exchange of data and information, prior notification, protection of the environment, public participation, precautionary approach, and polluter and user pays (see Articles 13-14, 18-20, \& 22-24). Unlike the Guarani Agreement which merely referenced similar international principles, the ITAS MoU offers considerable details on how these notions are to be construed and implemented. Finally, akin to the Genevese Convention and in contrast to the Guarani Agreement, the ITAS MoU emphasizes a balance between state sovereignty and state responsibility and avoids any explicit mention of sovereignty in its formulation (ITAS MoU 2014). 
Another particularly unique informal arrangement is the 1999 Memorandum of Understanding between the City of Juárez, Mexico Utilities and the El Paso Water Utilities Public Services Board (PSP) of the City of El Paso, Texas (Juárez-El Paso MoU, 1999). This mechanism is distinctive in that it was entered into by sub-national political entities without the oversight of the respective federal governments. While legally unofficial and unenforceable, the purpose of the Juárez-El Paso MoU is to encourage cooperation over the management and exploitation of the Hueco Bolson Aquifer and the Rio Grande River. It is also designed to facilitate the exchange of data and information, coordinate joint projects, develop compatible plans to secure water supplies, and create an Executive Committee tasked with fulfilling the objectives of the MoU. Given its parochial origin and perspective, it may be understandable that the Juárez-El Paso MoU makes no direct references to principles of international law or notions of sovereignty.

One other informal arrangement requires mentioning - the 1996 Memorandum of Agreement Related to Referral of Water Right Applications (BC-WA MoA) entered into by the Canadian province of British Columbia and the US State of Washington. Like the Juárez-El Paso MoU, the BC-WA MoA was adopted by sub-national political entities without the oversight of the respective federal governments. Moreover, like the JuárezEl Paso MoU, the BC-WA MoA was intended to encourage cooperation over a transboundary aquifer, the Abbotsford-Sumas Aquifer along with other related fresh water resources. The arrangement, however, is distinctive in that it calls for crossborder prior consultation, comment periods, and exchange of information on water quantity allocations within each party's territory that "could potentially significantly impact water quantity on the other side of the border" (BC-WA MoA 1996). To the extent that the BC-WA MoA applies to all surface water, ground water, and reservoir waters, it facilitates a form of cross-border public participation over decision-making related to shared water resources.

\section{UNILC Draft Articles and UN ECE Model Provisions}

The most profound milestones in the ongoing development of international law applicable to transboundary aquifers are the nineteen Draft Articles prepared by the UNILC, and the nine model provisions under the UN ECE Model Provisions. UNILC Draft Articles

In late 2008, following six years of intense work, the UNILC submitted this workproduct to the UNGA. As a preliminary matter, the UNGA acknowledged the UNILC's efforts, issued a resolution commending the nineteen Draft Articles to the attention of its Member States, and encouraged nations to take the articles into account when entering into bilateral and regional arrangements pertaining to the management of transboundary aquifers (UNGA Resolution 2008). 
Modeled largely on the 1997 UN Watercourses Convention, the chief substantive obligations include the well-respected international watercourse rules of equitable and reasonable utilization and no significant harm. In both instances, however, the principles are tailored to the unique qualities that differentiate surface waters from ground water resources. For example, the list of factors for assessing what constitutes equitable and reasonable utilisation includes notions relevant to ground water resources, such as "the natural characteristics of the aquifer or aquifer system," "the contribution to the formation and recharge of the aquifer or aquifer system," and "the role of the aquifer or aquifer system in the related ecosystem" (see Articles 5(1)(c), (d), and (i), UNGA Resolution 2008). Likewise, the no significant harm rule obligates aquifer states not to cause significant harm through "activities other than utilization of a transboundary aquifer ... that have, or are likely to have, an impact upon that transboundary aquifer" (see Article 6, UNGA Resolution 2008). This latter modification specifically relates to the distinct likelihood that non-aquifer utilisation activities undertaken above or around aquifers and their recharge and discharge zones could have detrimental impacts on those subsurface water bodies. Activities contemplated by this provision include industrial and agricultural operations in the recharge zone, mining activities in the aquifer matrix, and construction, forestry, and other activities that might affect the normal recharge or discharge processes (Eckstein, 2007).

Other notions found in the Draft Articles include obligations to regularly exchange data and information, provide prior notification of planned activities, safeguard ecosystems, protect recharge and discharge zones, prevent pollution, and monitor the aquifer (see Articles 8, 10,11, 12, 13, and 15) (UNGA Resolution 2008). Since their submission in 2008, the Draft Articles have appeared on the UNGA's agenda in 2011 and 2013. Each time, they were commended to the attention of UN Member States and tabled for a subsequent meeting. Interestingly, in the 2013, the UNGA commended the articles "as guidance for bilateral or regional agreements and arrangements for the proper management of transboundary aquifers (Report of the Sixth Committee, 2013)." While hardly a resounding endorsement, the "guidance" characterization suggests an elevated status for the Draft Articles (Eckstein \& Sindico, 2014). The Draft Articles are slated to appear again on the UNGA's agenda in late 2016.

\section{UN ECE Model Provisions}

The Model Provisions on Transboundary Groundwaters (Model Provisions), which were finalised in 2012 under the auspices of the UNECE, were drafted to provide guidance to states party to the UNECE Water Convention on the Convention's relevance to ground water resources. While the Model Provisions were designed to be non-obligatory, the nine provisions were specifically aligned to the Water Convention and crafted to take advantage of the binding regime established under that instrument. As a result, the Model Provisions do not necessarily manifest new principles pertaining to transboundary ground waters. Rather, they provide interpretative guidelines for and 
facilitate the implementation of the UNECE Water Convention with regard to such water bodies (Tanzi, et.al. 2015).

In reviewing the Model Provisions, it is clear that the authors drew some of their inspiration from the Draft Articles. Like the Draft Articles, the Model Provisions give considerable credence to the substantive obligations of equitable and reasonable utilization and no significant harm (see Provision 1). They also endorse the procedural obligations to regularly exchange data and information, monitor, prevent pollution, and provide prior notification of planned activities (see Provisions 3, 5, 6, and 8). The Model Provisions, however, also expand on the Draft Articles. For example, whereas the Draft Articles merely recommended the creation of joint institutional mechanisms to carry out the various objectives and obligations (see Articles 7 and 14), the Model Provisions mandate the creation of such bodies (see Provision 9). Moreover, the Model Provisions take the somewhat progressive steps of requiring that transboundary ground waters be used in a sustainable manner (see Provision 2), and mandating that transboundary ground and surface waters shall be managed in an integrated fashion (see Provision 4).

\section{The status of international law for transboundary aquifers}

The international law for managing and allocating transboundary ground water resources is still in a nascent state. There is yet no global instrument or series of customary norms that encapsulate the rules governing state conduct in this realm. Nevertheless, there is a growing international interest in the subject matter, as well as an increasing number of formal and informal arrangements between nations over shared ground water resources. Taken as a whole, trends and priorities can be discerned that could yet result in customary norms of international law. While the extent of state practices relating to the management of transboundary aquifer is still rather limited, a review of the arrangements discussed above hints at the emergence of a number of norms.

\section{Regular exchange of data and information}

Possibly the most palpable and consistent conduct emerging from state practice is a procedural obligation to regularly exchange data and information over transboundary aquifers. Appearing in all but one of the arrangements discussed in this study, the duty is fundamental to the sound management and protection of transboundary aquifers. Absent such sharing of information, aquifer states are faced with the consequences of the "blank map" syndrome whereby researchers on one or the other side of the border are able to characterise and describe only the portion of the aquifer located within their side (Sanchez, et.al. 2016). As a result, states are all-to-often unable to fully project and mitigate any deleterious cross-border consequences that might result from the utilisation of a particular transboundary aquifer (Eckstein 2007). 
In order to fulfill this duty, both logic and emerging state practice suggest that aquifer states should share on a continuing basis all available data and information on a transboundary aquifer. The precise type of material that must be shared, however, is not always spelled out in the various agreements. For example, the Al-Sag/Al-Disi Agreement simply refers to, "The collection and exchange of information, statements and studies and their analysis" (Al-Sag/Al-Disi Agreement, 2015), while the Model Provisions reference "the exchange of information and available data on the condition of transboundary groundwaters" (Model Provisions 2014). Nevertheless, it is obvious that the type of material that should be exchanged would have to pertain to the character, use, and functioning of the aquifer. Building on this reasoning, Article 8 of Draft Articles provides that such data and information should include material of a "geological, hydrogeological, hydrological, meteorological and ecological nature and related to the hydrochemistry of the aquifers or aquifer systems, as well as related forecasts" (UNGA Resolution 2008).

Using more aquifer-specific and descriptive language, the BC-WA MoA provides that the Parties shall "cooperate in sharing relevant water quantity information necessary to provide management of those water resources" and, subject to any domestic legal restricting disclosure, "commit to freely sharing and exchanging information on" water licenses and permits, as well as applications for new and modification of existing licenses/permits, and regional water availability and development studies (BC-WA MoA). Using equally focused language, the Juárez-El Paso MoU requires:

a) Sharing historical and current groundwater pumpage, sources of water, and water quality data.

b) Sharing technical support and information.

c) Sharing knowledge and experience regarding funding including, grants and/or loans, and determining the means by which to obtain such funds. $* * *$

f) Sharing information and analyzing issues related to population growth and the economy of the region to include in the regional planning processes, as well as focus on long-term needs (funding for new water resources) on both sides of the border.

(Juárez-El Paso MoU, 1999).

\section{Monitoring and generation of supplemental data and information}

A corollary procedural obligation to the duty to regularly exchange data and information is the duty to generate supplemental data and information on an on-going basis through monitoring and related activities. The obligation, which appears in a considerable majority of the arrangements considered in this study, acknowledges the need to maintain vigilance in managing a transboundary aquifer and, therefore, is also indispensable to fulfilling the duty to exchange data and information. 
The Genevese Convention, for example, is conceptualised largely on the notion of monitoring and further developing information about the aquifer. For example, it explicitly references monitoring in its title. Moreover, Chapter Four of the agreement addresses "Quantitative and Qualitative Monitoring of the Resource" and mandates periodic assessment of water quality and quantity as well as the exchange of that new information, while Article 17 requires the Parties to "maintain a monitoring network ... intended for the issuance of warnings in the case of accidental pollution likely to affect the water quality of the aquifer." Moreover, Article 10 mandates that "data from the extractions shall be performed by each user and reported at the end of the year to all users", while Article 16 provides that water pollution analyses "shall be made at regular intervals" (Genevese Convention, 2008).

In a similar vein, Agreement No. 2 under the NSAS Agreements utilises "Monitoring and Data Sharing" in its title and explicitly focuses on developing and exchanging new data and information:

Hence, it is herewith agreed between the four countries ... to monitor and share among them the following information:

- Yearly extraction in every extraction site, specifying geographical location and number of producing wells and springs in every site.

- Representative Electrical Conductivity measurements (EC), taken once a year in each extraction site, followed by a complete chemical analysis if drastic changes in salinity is [sic] observed.

- Water level measurements taken twice a year in the locations shown in the attached maps and tables. The proposed monitoring network is subject to changes upon the feedback of the National Coordinators of the concerned countries.

Using more general language, Provision 3 of the Model Provisions discusses monitoring in terms of "quantity and quality of transboundary groundwaters." The Provision, however, adds the critical requirements that the Parties must harmonise their monitoring standards and methodologies, agree on assessment criteria and parameters to be regularly monitored, and, where appropriate, link the monitoring of ground and surface waters (Model Provisions 2014).

The obligation to monitor and continuously generate additional data accords with the comparable duties imposed on riparians of transboundary surface waters. In his separate opinion in the Case Concerning the Gabčikovo-Nagymaros Project before the International Court of Justice (ICJ), Judge Christopher Weeramantry argued for emergence of a principle of continuing environmental impact assessment. In that opinion, Judge Weeramantry opined that "[a]s long as a project of some magnitude is in operation, [an environmental impact assessment] must continue, for every such project can have unexpected consequences; and considerations of prudence would point to the need for continuous monitoring" (Gabčikovo Case, 1997, p. 111). More recently, in the 
Case Concerning the Pulp Mills on the River Uruguay, the ICJ asserted that "once operations have started and, where necessary, throughout the life of the project, continuous monitoring of its effects on the environment shall be undertaken" (Pulp Mills Case, 2010, p. 205). The Court again recognized that obligation in the combined decision on the cases concerning Certain Activities Carried Out By Nicaragua in the Border Area and Construction of a Road in Costa Rica Along the San Juan River (San Juan River Cases, 2015, p. 60). While all three cases recognised this recurring obligation in the context of a transboundary watercourse, the logic utilised by the ICJ is equally and undeniably pertinent to transboundary ground water resources.

\section{Prior notification of planned activities}

Another procedural obligation found in a majority of the above-noted instruments is the duty to provide prior notification of planned activities. Where a planned project has the potential to adversely affect either the territory of another aquifer state or the transboundary aquifer itself, the acting state is obligated to notify other aquifer states of its plans. The purpose of such obligations is to allow potentially affected states to evaluate the possible consequences and to seek an understanding or compromise with the acting state (Eckstein 2007).

While the precise procedures required under this concept vary among the instruments, the basic notions of prior notification are well accepted in international water law. Under Paragraph 6 of Minute 242, Mexico and the US agreed to "consult with each other prior to undertaking any new development of either the surface or the groundwater resources, or undertaking substantial modifications of present developments, in its own territory in the border area that might adversely affect the other country" (Minute 242, 1973). Similarly, Article 15 of the Draft Articles would require aquifer states to provide "timely" notification "accompanied by available technical data and information ... to enable the notified State to evaluate the possible effects of the planned activities" (UNGA Resolution 2008). Indirectly emphasising consultation in good faith, Article 11 of the Guarani Agreement imposes the additional obligation that the party proposing the actions that may have a transboundary impact must delay implementation of those measures for at least six months while negotiating with the potentially affected state (Guarani Agreement 2009). Moreover, Provision 8 of the Model Provisions mandates an environmental impact assessment for all planned activities that are likely to have a significant effect on transboundary ground water resources, and requires that the assessment be transmitted to all potentially impacted state upon request (Model Provisions 2014).

In contrast to the above instruments, the Iullemeden MoU proffers much more rigorous requirements and processes for notification. While Article 27 provides the basic prior notification obligation for "activities, policies and strategies, plans, programs and projects proposed in the area, which may pose a risk to" the water resources of the 
transboundary aquifer or otherwise cause transboundary adverse impacts, Article 31 calls for "technical data and information, including the results of any evaluation of the environmental and social impact" to accompany the notification and requires the notifying state to "refrain from implementing or permitting the implementation of the planned measures" during a six month review process. Article 32 authorizes the notifying state to proceed with the planned activity in the absence of a response to the notification within six months. Article 33 requires that states engaged in consultations and negotiations over planned measures must do so "according to the principle of good faith, taking into account the legitimate interests of any other signatory State." Article 34 permits potentially affected states to request a state engaging in planned measures to comply with the notification obligations and requires disagreements on such obligations to be pursued through consultation and negotiation. Finally, Article 34 allows planned measures to proceed without notifications in emergency situations (Iullemeden MoU 2014).

\section{Creation of institutional mechanisms to facilitate or implement the arrangement}

One of the most interesting trends perceived from the various arrangements is the creation of joint institutional mechanisms to carry out the objectives of the various regimes. This is particularly noteworthy because of the 276 rivers and lakes found on Earth, less than 40\% (105) employ some type of water management institution (Drieschova \& Eckstein 2014). In contrast, of the handful of arrangements that have been implemented or proposed for a transboundary aquifer, all but two have implement or propose some type of joint institutional mechanism. Moreover, the Draft Articles in Articles 7 (General obligation to cooperate) and Article 14 (Management), as well as the Model Provisions in Provision 9, clearly contemplate the creation of such mechanisms. While the structures and levels of authority granted these entities vary across the regimes, it remains clear that most aquifer nations that have entered into a cross-border arrangement recognize both the value of and the need for institutional and other cooperative mechanisms to facilitate and realize the sound and sustainable management of their shared ground water resources.

For example, the Model Provisions, Guarani Agreement, Al-Sag/Al-Disi Agreement, and Juárez-El Paso MoU, all call for the creation of an institutional mechanism to carry out the purposes of the respective agreements. The Model Provisions and Guarani Agreement provide the simplest iteration of this obligation and offer no additional instructions about the structure and operation of such an entity (Provision 9, Model Provisions 2014; Article 15, Guarani Agreement 2010). The Guarani Agreement, however, does provide in Article 15 that the mechanism would be established in accordance with Article VI of the 1969 Treaty of the Plata River Basin, and stipulates in Article 17 that it will be tasked with helping to resolve disputes by evaluation situations and formulating recommendations (Guarani Agreement 2010). Article 3 of the AlSag/Al-Disi Agreement offers slightly more details and notes that the institutional 
mechanism is composed of representatives of the national water resources agencies in the two member states, and that its mandate includes: "The supervision and observation" of ground water levels, quality, and extraction; "The collection and exchange of information, statements and studies and their analysis" related to the aquifer; and the submission of such information and analyses to the two governments (Al-Sag/Al-Disi Agreement 2015). Likewise, the Executive Committee of the Juárez-El Paso MoU is tasked in Paragraph 2 with data sharing and project coordination obligations, and is also assigned to facilitate a number of locally-specific activities, including completion of a feasibility study that was begun prior to implementation of the MoU (Juárez-El Paso MoU 1999).

In a similar vein, the Genevese Convention creates a commission whose purpose is to implement the agreement. The Genevese Aquifer Management Commission, however, has more extensive authorities than under the above-noted arrangements. Its mandate, for example, as described in Article 2, includes proposing an annual aquifer utilisation program, providing technical opinions on construction of new ground water extraction operations and modification of existing equipment, and performing audits of investment and operational costs related to the recharge installation. It is also responsible for overseeing waterworks and equipment construction (Article 5), record water extractions (Article 6), collect water level and quality data (Article 10), establish water quality analysis criteria (Article 16) (Genevese Convention 2008).

In contrast to the above five arrangements, where creation of a joint institution was an important albeit a secondary component to the agreement, the NWSAS Agreement, the Iullemeden MoU, and the Constitution of the Joint Authority, by their very titles and purposes, were formulated and implemented specifically to create a joint cooperative mechanism. The NWSAS Agreement, for example, created a "Consultative Mechanism" to "coordinate, promote and facilitate the rational management of the NWSAS water resources" (Parag. I, NWSAS Agreement 2002)," while the Iullemeden MoU created an identically-named mechanism "to promote and foster cooperation between the Signatory States ... based on solidarity and reciprocity for a sustainable, equitable, coordinated and collaborative use of the ITAS water resources" (Article 3, Iullemeden MoU 2014). While the NSA Constitution does not include a purpose statement, the "tasks" outlined in Article 3 of the agreement are representative of the functions and responsibilities assigned to the mechanisms under each of these three agreements: collect and develop all data and information relevant to the shared aquifer; promote and facilitate additional studies; formulate proposals for the sustainable management of the aquifer; and undertake and facilitate appropriate training programs and other mechanisms for the disseminating of information (NSA Constitution 1992).

\section{Substantive obligations}


While the above obligations may properly be described as procedural in nature, the various arrangements discussed here also endeavor to create a number of substantive responsibilities. The most prolific of these is the Iullemeden MoU, which commits Signatory States to such principles as: equitable and reasonable utilization, nondamaging use, sustainable development, ecosystem protection, precaution, and polluter pays (Iullemeden MoU 2014).

A closer review of the arrangements, however, suggests no conclusive trends of crosscutting substantive norms emerging from such practices of states. Varying references to adverse transboundary effects, impacts, and harm are found in two formal instruments (Paragraph 6, Minute 242; Articles 6 \& 7, Guarani Agreement), one informal mechanism (Article 20, Iullemeden MoU), and both the Draft Articles (Article 6) and Model Provisions (Provision 1). While Minute 242 simply refers to possible transboundary "adverse effect" in the context of prior notification, the others impose a due diligence obligation to prevent, control, and reduce such impacts. Of these five arrangements, all except Minute 242 also refer to the cornerstone international water law principle of equitable and reasonable utilization (Article 13, Iullemeden MoU; Article 4, Guarani Agreement; Article 4, Draft Articles; and Provision 1, Model Provisions). However, only the Iullemeden MoU and the Draft Articles offer factors to be taken into account when assessing what uses may be deemed equitable and reasonable.

Aside from these few similarities, the lack of consistent appearance of additional principles in the various instruments and mechanisms reviewed in this study indicates that no other norms or obligations are trending toward customary status. Notwithstanding, as the practice of states pertaining to transboundary aquifers continues to evolve and new agreements are forged, this conclusion should be periodically reevaluated.

\section{Considerations for further development of the law}

While surface and ground water resources are both integral components of the hydrologic cycle and share numerous similarities, ground water possesses a number of unique characteristics that must be considered carefully when contemplating regulatory tools for managing the resource. For example, the relatively slower flow rates of water through subsurface strata, as compared to water flow in rivers, can impair an aquifer's natural filtration abilities and, thereby, their capacities to reclaim and cleanse themselves of pollutants. As a result, ground water can be more vulnerable than surface water to agricultural, industrial, and municipal pollution as well as other sources of contamination (Eckstein 2007). Moreover, because of the geographic extent of most aquifers and the challenges associated with monitoring underground formations, the artificial reclamation of a polluted aquifer can be prohibitively complex and expensive. As a result, once an aquifer is contaminated, it may be rendered unusable for years, decades or longer (Eckstein 2007). Among other issues, this raises 
the question of whether the threshold for actionable harm should be different for transboundary ground water resources as compared to cross-border surface water bodies.

Furthermore, the "functioning" of aquifers - which refers to how particular aquifers work or behave as aquifers - also must be taken into account when formulating appropriate regulatory mechanisms for the sound management of transboundary ground water resources. Aquifer functioning encompasses how subsurface strata can store and transport water, dilute wastes and other contaminants, provide a habitat for aquatic biota, serve as a source of fresh water and nutrients to aquifer-dependent ecosystems, and even provide geothermal heat. Each of these characteristics is dependent on the particular aquifer's structure, hydrostatic pressure, hydraulic conductivity, interaction with other geophysical phenomenon, and mineralogical, biological, and chemical attributes. Moreover, all of these traits may be interdependent to the extent that an aquifer's sustained operation as a dynamic hydrogeologic system depends on the continuation of a particular function or series of functions (Heath 2004). If any of these natural characteristics were to be impaired or destroyed, it could detrimentally affect the viability and integrity of the aquifer as a whole, as well as communities and ecosystems dependent on that aquifer. Accordingly, in order to manage a transboundary aquifer in ways that maximizes both its utility and sustainability, regulatory mechanisms must take into account the functioning as well as the unique vulnerabilities and characteristics of each shared subsurface water body.

In addition, when contemplating appropriate regulatory mechanisms for the sound management of transboundary ground water resources, the recharge and discharge processes of each aquifer also require special attention. Recharge and discharge zones regulate the flow and quality of water moving into and out of aquifers. Hence, these processes, as well as the geographical area in which they operate, must be properly maintained and protected. In the case of recharge zones, this consists of ensuring both the quantity and quality of water flowing through the recharge zone and entering the aquifer. Thus, recharge zone protection might include restrictions on industrial and municipal developments in the recharge area, as well as constraints on agricultural activities that might contaminate the recharge area and, thereby, the aquifer. Similarly, discharge zones protection could include restrictions on construction and other activities that might inhibit the discharge process, water flow within the aquifer, the location of the water table, or the aquifer's natural cleansing abilities. Restrictions for both zones might also include limitations on mining activities that remove or modify the strata within the recharge or discharge area.

The above concerns do not reflect all of the characteristics, issues, and gaps in knowledge that must be addressed. Others concerns and topics that should be considered include: the relevance of the principles of no significant harm and equitable and reasonable use to transboundary aquifers; if relevant, whether the no significant 
harm standard is subordinate or superior to that of equitable and reasonable use in the context of transboundary aquifers; mechanisms to harmonise metadata and methodologies produced by aquifer riparians pertaining to a shared aquifer; whether the exploitation of non-recharging aquifers, as compared to recharging aquifers, require a distinct legal and governance regime.

\section{Conclusion}

Transboundary ground water resources today play a critical role in providing fresh water for people, industries, nations and the environment worldwide. For billions of people, they serve as the bulwark against the challenges posed by expanding demands for freshwater and the declining supplies resulting from overexploitation and climatic changes. As a result, transboundary aquifers are now receiving greater international attention by overlying nations, non-governmental advocacy groups, and UN entities. Moreover, many states around the world are beginning to pursue various strategies for their exploitation and management.

While the level of attention that these aquifers are receiving still pales in comparison with that paid to rivers and lakes, it is reasonable to expect that nations will continue to explore their transboundray aquifers. The value of these resources is undeniable, and growing water scarcity is driving many nations to investigate all new possibilities. As a result, it is also reasonable to expect that more states will engage their cross-border neighbors in an effort to collaborate and coordinate their activities. Moreover, as cooperation over transboundary aquifers expands and the number of formal and informal arrangements grows, as is certain to happen, trends and priorities will become more evident and will lead to the development of more definite customary norms for the management of transboundary ground water resources.

\section{References}

Articles, Books, and Reports

Almássy, E. and Busás, Zs., 1999. UN/ECE Task Force on Monitoring \& Assessment, Guidelines on Transboundary Ground Water Monitoring, Volume 1: Inventory of Transboundary Ground Waters, UN Economic Commission for Europe.

Brownlie, I., 1998. Principles of Public International Law $5^{\text {th }}$. USA: Oxford University Press.

Burchi, S., 1999. National regulation for groundwater: options, issues and best practices. In S.M.A. Salman, ed. Groundwater: Legal and Policy Perspectives, Proceedings of a World Bank Seminar, Washington, DC: The World Bank, 55-67. 
Drieschova, A. and Eckstein, G., 2014. Cooperative Transboundary Mechanism, in Transboundary Water Governance: Adaptation to Climate Change, 51-79.

Eckstein, G., 2012. Rethinking Transboundary Ground Water Resources Management: A Local Approach along the Mexico-U.S. Border, Georgetown International Environmental Law Review, 25(1), 95-128.

Eckstein, G., 2007. Commentary on the UN International Law Commission's Draft Articles on the Law of Transboundary Aquifers, Colorado Journal of International Environmental Law \& Policy, 18(3), 537-610.

Eckstein, G., 2003. A hydrogeological approach to transboundary ground water resources and international law, American University International Law Review, 19(2), 201-258.

Eckstein, G. and Hardberger, A., 2008. State practice in the management and allocation of transboundary groundwater resources in North America, Yearbook of International Environmental Law, 18, 96-125.

Eckstein, G. and Sindico, F., 2014. The Law of Transboundary Aquifers: Many ways of going forward, but only one way of standing still, Review of European, Comparative \& International Environmental Law, 23(1), 32-42.

Hayton, R. and Utton, A., 1989. Transboundary groundwaters: The Bellagio Draft Treaty, Natural Resources Journal, 29, 663-722.

Heath, R.C., 2004. Basic Ground-Water Hydrology, Water Supply Paper 2220. U.S. Geological Survey.

IGRAC 2015, Transboundary Aquifers of the World - Special Edition for the $7^{\text {th }}$ World Water Forum 2015. Available at: http://www.un-igrac.org/download/file/fid/179 [Accessed 15 December 2015].

International Court of Justice, 1997. Case Concerning the Gabčikovo-Nagymaros Project, Separate Opinion of Judge Weeramantry, Judgment of 25 September 1997. Available from: http://www.icj-cij.org/docket/files/92/7383.pdf [Accessed 22 December 2015].

International Court of Justice, 2010. Case Concerning the Pulp Mills on the River Uruguay, Judgment of 20 April 2010. Available from: http://www.icjcij.org/docket/files/135/15877.pdf [Accessed 15 December 2015].

International Court of Justice, 2010. Cases Concerning Certain Activities Carried Out By Nicaragua in the Border Area and Construction of a Road in Costa Rica Along the San Juan River, Judgment of 16 December 2015. Available from: http://www.icjcij.org/docket/files/152/18848.pdf [Accessed 25 March 2016].

International Law Association, 2004. Berlin Conference on Water Resources Law. Available from:

http://internationalwaterlaw.org/documents/intldocs/ILA Berlin Rules-2004.pdf [Accessed 15 December 2015].

McCaffrey, S., 2007. The Law of International Watercourses $2^{\text {nd }}$, USA: Oxford University Press. 
McCaffrey, S. C., 2011. The International Law Commission's flawed Draft Articles on the Law of Transboundary Aquifers: The Way Forward, Water International, 36, 566572.

Nigeria Politics Online, 2014. FG seals deal with 6 Countries on water resources, Nigeria Politics Online, October 29, 2014. Available from:

http://nigeriapoliticsonline.com/fg-seals-deal-with-6-countries-on-waterresources/ [Accessed 15 December 2015].

Puri, S. and Aureli, A., 2009. Atlas of Transboundary Aquifers, Paris: UN Educational, Scientific and Cultural Organization.

Regional Strategic Action Plan for the Nubian Aquifer System. 18 September 2013. Available from:

http://internationalwaterlaw.org/documents/regionaldocs/Regional Strategic Acti on Plan for the Nubian Aquifer.pdf [Accessed 22 December 2015].

Report of the Sixth Committee, The Law of Transboundary Aquifers (UN Doc. A/68/470, 19 November 2013). Available from:

http://www.un.org/ga/search/view doc.asp?symbol=A/68/470 [Accessed 15 December 2015].

Sanchez, Rosario, et.al., (forthcoming 2016). Identifying and Characterizing Transboundary Aquifers Along the Mexico-US Border: An initial assessment, Journal of Hydrology

Sindico, F. and Hawkins, S., 2015. The Guarani Aquifer Agreement and Transboundary Aquifer Law in the SADC: Comparing Apples and Oranges?, Review of European Community \& International Environmental Law, 24(3), 318-329.

Stephan, R.M., ed. 2006. Transboundary Aquifers: Managing a Vital Resource - The UNILC Draft Articles on the Law of Transboundary Aquifers, Paris: UN Educational, Scientific and Cultural Organization.

Tanzi, Attila, et.al. (Eds.) 2015. The UNECE Convention on the Protection and Use of

Transboundary Watercourses and International Lakes: Its Contribution to International Water Cooperation, Brill/Nijhoff.

UN Economic Commission for Europe, 2014. Model Provisions on Transboundary Groundwaters, ECE/MP.WAT/40. Available from:

https://www.unece.org/fileadmin/DAM/env/water/publications/WAT model pro visions/ece mp.wat 40 eng.pdf [Accessed 22 January 2016].

UN Educational, Scientific and Cultural Organization and World Water Assessment Programme, 2003. Water for People, Water for Life, The United Nations World Water Development Report. UN World Water Assessment Programme.

UN Environmental Programme, 2002. Atlas of International Freshwater Agreements. UN General Assembly, 2008. Resolution on the Law of Transboundary Aquifers,

A/RES/63/124. Available from:

http://internationalwaterlaw.org/documents/intldocs/UNGA Resolution on Law o f Transboundary Aquifers.pdf [Accessed 22 December 2015].

UNESCOPRESS, 2008. UNESCO publishes first world map of underground transboundary aquifers, Press Release No. 2008-108, October 22, 2008. 
Villar, P.C. \& Wagner, C.R., 2013. The Agreement on the Guarani Aquifer: Cooperation without conflict, Global Water Forum. Available from:

http://www.globalwaterforum.org/2013/09/02/the-agreement-on-the-guaraniaquifer-cooperation-without-conflict/ [Accessed 22 December 2015].

Watkins, J., 2006. Libya's thirst for 'fossil water'. BBC News, 18 March. Available from: http://news.bbc.co.uk/2/hi/science/nature/4814988.stm [Accessed 22 December 2015].

World Bank, 2009. Assessment of Restrictions on Palestinian Water Sector Development, Report No. 47657-GZ.

Wouters, P. and Moynihan, R., 2013. Benefit Sharing in the UN Watercourses Convention and under International water law, in F. Rocha Loures and A. Rieu-Clarke (Eds.), The UN Watercourses Convention in Force: Strengthening International Law for Transboundary Water Management

Yamada, C., 2011. Codification of the Law of Transboundary Aquifers (Groundwaters) by the United Nations. Water International, 36(5), 557-565.

Treaties, Agreements and other International Arrangements

Agreement between the Governments of Great Britain and France with regard to the Somali Coast. Done on February 1888. Reprinted in Oakes, Augustus H. and Maycock, Willoughby (1897). British and Foreign State Papers 1890-1891. p. 672

Agreement between the Government of the Hashemite Kingdom of Jordan and the Government of the Kingdom of Saudi Arabia for the Management and Utilization of the Ground Waters in the Al-Sag/Al-Disi Layer. Done in Riyadh, Saudi Arabia, 30 April 2015. Available from:

http://internationalwaterlaw.org/documents/regionaldocs/Disi Aquifer Agreemen t-English2015.pdf [Accessed 15 December 2015].

Constitution of the Joint Authority for the Study and Development of the Nubian Sandstone Aquifer Waters, 1992. Available from:

http://internationalwaterlaw.org/documents/regionaldocs/Constitution of the Joi nt Authority-Nubian Sandstone Aquifer.pdf [Accessed 23 December 2015].

Convention on the Protection, Utilisation, Recharge and Monitoring of the Franco-Swiss Genevese Aquifer between the Community of the 'Annemassienne' region, the Community of the 'Genevese' Rural Districts, and the Rural District of Viry, on one part, The Republic and Canton of Geneva, on the other. Done in Geneva, 18 December 2007; in force on 1 January 2008. Available from: http://internationalwaterlaw.org/documents/regionaldocs/2008Franko-SwissAquifer-English.pdf [Accessed 22 December 2015].

Establishment of a Consultation Mechanism for the Northwestern Sahara Aquifer System (SASS). Done in Rome, 19-20 December; endorsed 6 January 2003 (Algeria), 15 February 2003 (Tunisia), 23 February 2003 (Libya). Available from: 
http://www.fao.org/docrep/008/y5739e/y5739e05.htm\#bm05.2.1 [Accessed 15 December 2015].

Guarani Aquifer Agreement. Done in San Juan, Argentina, 2 August 2010. Available from: http://internationalwaterlaw.org/documents/regionaldocs/Guarani Aquifer Agree ment-English.pdf [Accessed 20 December 2015].

Memorandum of Agreement Related to Referral of Water Right Applications between the State of Washington as represented by the Department of Ecology and the Province of British Columbia as represented by the Minister of Environment, Lands and Parks. Done in 10 October 1996. Available from:

http://internationalwaterlaw.org/documents/regionaldocs/Local-GWAgreements/1996-BC-WA-Water-Right-Referral-Agreement.pdf [Accessed 15 December 2015].

Memorandum of Understanding between City of Juárez, Mexico Utilities and the El Paso Water Utilities Public Services Board of the City of El Paso, Texas. Done on 6 December 1999. Available from:

http://internationalwaterlaw.org/documents/regionaldocs/Local-GWAgreements/El Paso-Juarez MoU.pdf [Accessed 15 December 2015].

Memorandum of Understanding for the Establishment of a Consultation Mechanism for the Integrated Management of the Water Resources of the Iullemeden, Taoudeni/Tanezrouft Aquifer Systems (ITAS) (Algeria, Benin, Burkina Faso, Mali, Mauritania, Niger, Nigeria). Done in Abuja, Nigeria, 28 March 2014. Available from: http://internationalwaterlaw.org/documents/regionaldocs/Iullemeden MOU2014.pdf [Accessed 22 December 2015].

Minute 242: Permanent and Definite Solution to the International Problem of the Salinity of the Colorado River. International Boundary and Water Commission. Done on 30 August 1974. Available from:

http://www.ibwc.gov/Files/Minutes/Min242.pdf [Accessed 15 December 2015].

Programme for the Development of a Regional Strategy for the Utilisation of the Nubian Sandstone Aquifer System (NSAS). Done in Tripoli, 5 October 2000. Available from: http://www.fao.org/docrep/008/y5739e/y5739e05.htm [Accessed 22 December 2015].

Treaty of Limits between Portugal and Spain. Signed at Lisbon, 29 September 1864. Treaty between the United States and Mexico on the Utilization of Waters of the Colorado and Tijuana Rivers and of the Rio Grande. Signed in Washington, DC, 14 November 1944.

UN Convention on the Law of Non-navigational Uses of International Watercourses, 1997. G.A. Res. 51/229, UN GAOR, 51 st Sess., UN Doc. A/RES/51/229 (1997).

UNECE Convention on the Protection and Use of Transboundary Watercourses and International Lakes. Done at Helsinki, 17 March 1992. Available from: http://www.unece.org/env/water/pdf/watercon.pdf [Accessed 22 December 2015]. 


\section{$\underline{\text { Endnotes }}$}

${ }^{\mathrm{i}}$ Customary international law refers to international law that is based on the accepted practices of nations rather than on codified rules. It emerges from the broad and consistent conduct of states that is undertaken by a belief that such behavior is both legally appropriate and mandated (Brownlie, 1998).

ii The ITAS MoU is considered here as an unofficial arrangement. Conceptualized as a Memorandum of Understanding, the ITAS MoU technically cannot be deemed a binding instrument. Yet, in its final provisions, it references the "binding" nature of decision taken by the Consultative Mechanism (Article 47) as well as the need to ratify the MoU for it to enter into force (Article 53). Moreover, the details and language used in the MoU suggest an intention by the parties to comply with the terms of the resulting agreement once it comes into force. Notwithstanding, as of this writing, only Nigeria has processed the MoU's ratification within its domestic system (Nigeria Politics Online, 2014). 